\title{
AN EMPIRICAL STUDY ON EFFECT OF BRANDS ON PRODUCT RETURNS
}

\section{Dr. TVB MURALI MOHAN}

Ex-Research Scholar, ISBR Research centre, Bengaluru

Ph: 9449508858

Email id: tvb_muralimohan@yahoo.co.in

\section{Dr .T KARPAGAM}

Professor

ISBR Research Centre, Bangalore

\begin{abstract}
Over the last couple of decades India has been the epicentre of consumer demand fuelled by a phenomenal GDP growth. Due to the burgeoning demand of Mobile Phones, the Indian industry is finding it difficult to meet the domestic demand and hence the import of Mobile Phones is increasing at a rapid rate. There by, the Indian consumer is provided with a variety of choices in terms of availability of brands, affordable prices and so on facilitating faster pre-purchase decisions.

In the past few years, there has been a significant change in the shopping pattern of consumers from In store shopping to Online shopping in which returns are more likely due to a lack of "touch and feel" experience with the product prior to purchase.

In both the processes, Product return is a necessary part of the exchange process between companies and customers. Industry data suggests that returns account for approximately $12 \%$ of total sales in India and that a significant portion of products are returned
\end{abstract}


for reasons other than product failure - e.g., change of mind, found a lower price elsewhere, or fraudulent and unethical reasons. Thus, Product returns are no small part of the firm-customer exchange process (J. Andrew Petersen (University of North Carolina) and V. Kumar (Georgia State University) as product returns impose significant financial costs to retailers and to consumers alike. "However, these same returns create long-term value because customers who feel there is little risk in making the wrong purchase keep coming back".

This Empirical study focuses on understanding the interplay between the brand and consumers' return behaviour, and also the relation between product performance and product return behaviour.

Keywords : Brand, Consumer demand, online shopping, product returns, return factors, returns behaviour, etc

\section{INTRODUCTION}

\subsection{Return Process}

The Return Process refers to the steps a consumer must take from purchasing a product, to returning the product, to receiving a refund. One of the main constraints of this Return Process is that it is not an easy transition from purchase to return to refund inspite of consumers desiring a streamlined process. This includes things like the number of steps involved and the amount of questions or prerequisites required prior to a product return

According to Mike Abary, Senior Vice President, Sony Inc., in WSJ 2009, “Defects aren't even in the top three reasons for returns for products sold online, it's because difference in expectations". 
Broadly speaking, products are returned because either they do not function properly or because their function is no longer needed.

Returned products can take the form of end-of-life returns, where the product has been used by the customer and has reached the end of useful life mostly due to obsolescence or substantial damage, and can only be recycled for materials recovery. or commercial/consumer returns, where the product is returned before use. i.e., products that have experienced little or no use by consumers - they are a result of liberal return policies by retailers and are mostly not defective (Ferguson, Guide, \& Souza, 2006).

\subsection{The Present Study}

India is growing through a phase of digital revolution during the past five years driven by rising disposable incomes, increasing smart phone usage, exposure to Digital media which is significantly impacting the dynamics of consumer electronics retail industry.

The Indian demographic profile has also undergone a characteristic change due to the increasing Gen-Y working class population, working women and the Indian middle class population which has triggered new social, technological and economic trends. In addition, Information on availability of multiple products, comparison of products, Schemes providing cashback and discounts, increasing network infrastructure development and usage of wireless 3G and 4G technologies have contributed to the tremendous growth of Mobile Phone industry in India.

Even though Online market places provide a seamless experience to its customers with the option of easy returns due to quality issues, there is still a lot of challenges faced by the retailers.

According to a report on product returns in India by Amazon in 2018, Amazon India has the highest return rate as compared to all other markets it operates in other countries. It states that around $30 \%$ of gross merchandise value is the product returned or cancelled. Other Homegrown e-tailers like Flipkart and Snapdeal have also reported a return rate in the range of 10-20\%.

The existing literature has provided very little information about the reasons for Mobile Phone returns in India and there is an urgent need to effectively manage returns by manufacturers and 
sustain the growth in a highly competitive business environment and in this context this study has emerged.

\subsection{Objectives of the study}

a) To analyse the relationship between Product Brand and product return behavior of consumers wrt mobile Phones

b) To analyse the relationship between product performance and product return behavior of consumers

\section{Literature Review}

From a customer's perspective, the most desirable return policy would be to get full refunds, no questions asked. However for a retailer this is not always desirable because a retailer loses the profit it would have made on that product, and because he has to with the deal with the costs associated with moving the product through the reverse supply chain (TibbenLembke\& Rogers, 2002).

Few studies in marketing literature have focused on strengthening and maintaining brand attitudes following a purchase. Much less attention has been paid to the emotion consumers experience after purchase as they possess and consume the product (Richins, 2008). All this despite the fact that the post purchase phase has a strong impact on repurchase behavior, word of mouth and customer loyalty (Elzinga et al, 2009). In addition, much of the existing post purchase literature on consumer behavior is focused on how to prevent and handle problems such as regret (cognitive dissonance), or how to deal with the complaining customer.

Nada Nasr Bechwati and Wendy Schneier Siegal (2005) in the study "The Impact of the Pre choice Process on Product Returns" introduce a framework to help researchers understand the mechanisms underlying product returns. When faced with disconfirming information favoring a new brand, inoculated consumers who are presented with choice alternatives sequentially are less likely to return a brand than consumers who are exposed solely to positive information about the chosen brand at a pre-purchase stage.

Meyer C. and Schwager A (2007) in the study titled "Understanding customer experience" states Direct contact occurs while purchasing, usage, and service and is initiated by the 
customer most of the times. Indirect contact involves unplanned encounters with representatives from the companies offering products, service or brands and translates into word-of-mouth recommendations or criticisms, advertising, news reports, reviews etc.

\section{Research Gaps}

Based on the intense literature review, It was found that literature on return policies and consumer product returns is very limited. Thorough analysis of the literature has revealed many gaps and has evolved into many concepts which have not been studied so far. The gaps in literature is discussed in the following paragraph.

- The literature on consumer behavior focusses mainly on Customer satisfaction, retention and loyalty.

- In the marketing literature, customer satisfaction, customer loyalty and customer repurchase intention has been the subject of many research studies

There has been no attempt in the reviewed studies to empirically test the effect of product brand and product performance on consumer product behavior in mobile phone industry

\section{Research Method}

This study is basically exploratory and analytical in nature.

\subsection{Sampling}

Sampling method: Convenient sampling, which is a non-probability sampling technique. Selection of Sample: Research has been done and conclusions were drawn about large group of consumers by studying a sample of total population. The study was conducted in Bangalore City and approx.. 150 respondents were contacted, so that we can make inferences about the population based on that sample.

\subsection{Data Collection}

Primary data was collected from 150 respondents who were the ultimate consumers of Mobile Phones with different demographic profiles The responses were on online mode using questionnaire through google forms and the responses were received from various respondents spread throughout Bangalore city. 
For secondary data, the different traditional sources like secondary literature, Digital sources such as internet, online journals, encyclopaedia, books, websites, search engines like Google Scholar, Thesis databases like Shodhganga, etc. have also been accessed.

\subsection{Data Analysis}

Table 3.3.1 Frequency Distribution of Years of usage of Mobile Phones.

\begin{tabular}{|c|l|c|c|}
\hline S1 No. & Particulars & $\begin{array}{l}\text { No. of } \\
\text { respondents }\end{array}$ & Percentage \\
\hline \multicolumn{2}{|l|}{ Years of usage of Consumer electronics products } \\
\hline 1 & Less than 1 year & 6 & 4.2 \\
\hline 2 & 1 to 3 years & 30 & 19.5 \\
\hline 3 & 3 to 5 years & 42 & 28.1 \\
\hline 4 & 5 to 8 years & 45 & 30.2 \\
\hline 5 & More than 8 years & 27 & 18.0 \\
\hline & Total & 150 & 100 \\
\hline
\end{tabular}

Source : Survey data

Table 3.3.2 Frequency Distribution of users based on Mobile Phone brands

\begin{tabular}{|c|l|c|c|}
\hline S1 No. & $\begin{array}{l}\text { Mobile Phone } \\
\text { Brand }\end{array}$ & $\begin{array}{l}\text { No. of Mobile } \\
\text { Phone users }\end{array}$ & Percentage \\
\hline 1 & Samsung & 41 & 27.3 \\
\hline 2 & Oppo & 12 & 8 \\
\hline 3 & Apple & 10 & 6.7 \\
\hline
\end{tabular}




\begin{tabular}{|c|l|c|c|}
\hline 4 & Motorola & 30 & 20 \\
\hline 5 & Micromax & 5 & 3.3 \\
\hline 6 & Lenovo & 4 & 2.7 \\
\hline 7 & INTEX & 3 & 2 \\
\hline 8 & Oneplus & 3 & 2 \\
\hline 9 & Xiaomi & 40 & 26.7 \\
\hline 10 & Celkon & 2 & 1.3 \\
\hline & Total & 150 & 100 \\
\hline
\end{tabular}

Source : Survey data

It can be concluded that maximum number of the respondents are using Samsung brand mobile phones.

Table 3.3.3 Distribution showing return behavior of respondents

\begin{tabular}{|c|l|c|c|}
\hline $\begin{array}{r}\text { S1 } \\
\text { No. }\end{array}$ & Particulars & $\begin{array}{c}\text { No. of } \\
\text { respondents }\end{array}$ & Percentage \\
\hline \multicolumn{4}{|c|}{ Product return within a year } \\
\hline 1 & Yes & 42 & 28 \\
\hline 2 & No & 108 & 72 \\
\hline & Total & 150 & 100 \\
\hline
\end{tabular}

The above table clearly explains that out of 600 respondents 168 respondents i.e., $28 \%$ of the respondents have returned the product within a year of purchase whereas 432 respondents i.e., $72 \%$ of the respondents have not returned the product within a year of purchase. Therefore 
it can be concluded that majority of the respondents have not returned the product within a year of purchase.

\subsection{Testing of Hypothesis}

\section{Hypothesis 1}

$\mathrm{HO}$ : There is no association between product brand and product return behavior of consumers

$\mathrm{H} 1$ : There is association between product brand and product return behavior of consumers

\begin{tabular}{|c|c|c|c|c|c|}
\hline \multicolumn{6}{|c|}{ Chi-Square Tests of Hypothesis } \\
\hline & Value & $\mathrm{df}$ & $\begin{array}{l}\text { Asymp. Sig. } \\
\text { (2-sided) }\end{array}$ & $\begin{array}{l}\text { Exact Sig. } \\
\text { (2-sided) }\end{array}$ & $\begin{array}{l}\text { Exact Sig. } \\
\text { (1-sided) }\end{array}$ \\
\hline Pearson Chi-Square & $2.081^{\mathrm{a}}$ & 1 & .149 & & \\
\hline Continuity Correction $^{b}$ & 1.599 & 1 & .206 & & \\
\hline Likelihood Ratio & 2.110 & 1 & .146 & & \\
\hline Fisher's Exact Test & & & & .160 & .103 \\
\hline $\begin{array}{l}\text { Linear-by-Linear } \\
\text { Association }\end{array}$ & 2.067 & 1 & .150 & & \\
\hline $\mathrm{N}$ of Valid Cases & 150 & & & & \\
\hline \multicolumn{6}{|c|}{ a. 0 cells $(0.0 \%)$ have expected count less than 5 . The minimum expected count is 20.05 . } \\
\hline b. Computed only for & able & & & & \\
\hline
\end{tabular}

Source : SPSS Output

\section{DECISION AND CONCLUSIONS}

Since the Chi-square value $\mathrm{X}^{2}=2.081 \&$ p-value $(=0.149)$ is more than our chosen significance level $(\alpha=0.05)$, The Null hypothesis is accepted. Hence, There is no association between product brand and product return behavior.

\section{Hypothesis No. 2}

$\mathrm{H}_{0}$ : The attributes satisfaction with product performance and product return behavior are independent 
$\mathrm{H}_{1}$ : The attributes satisfaction with product performance and product return behavior are not independent

\begin{tabular}{|c|c|c|c|c|c|}
\hline \multicolumn{6}{|c|}{ Chi-Square Tests of Hypothesis } \\
\hline & Value & $\mathrm{df}$ & $\begin{array}{c}\text { Asymp. Sig. } \\
\text { (2-sided) }\end{array}$ & $\begin{array}{l}\text { Exact Sig. } \\
\text { (2-sided) }\end{array}$ & $\begin{array}{l}\text { Exact Sig. } \\
\text { (1-sided) }\end{array}$ \\
\hline Pearson Chi-Square & $25.890^{\mathrm{a}}$ & 1 & .000 & & \\
\hline Continuity Correction $^{b}$ & 23.172 & 1 & .000 & & \\
\hline Likelihood Ratio & 22.666 & 1 & .000 & & \\
\hline Fisher's Exact Test & & & & .000 & .000 \\
\hline $\begin{array}{l}\text { Linear-by-Linear } \\
\text { Association }\end{array}$ & 25.847 & 1 & .000 & & \\
\hline $\mathrm{N}$ of Valid Cases & 600 & & & & \\
\hline \multicolumn{6}{|c|}{ a. 1 cells $(25.0 \%)$ have expected count less than 5 . The minimum expected count is 4.73 . } \\
\hline
\end{tabular}

Source : SPSS output

\section{DECISION AND CONCLUSIONS}

Since the Chi-square value $\mathrm{X}^{2}=25.890 \&$ p-value $(=0.000)$ is less than our chosen significance level $(\alpha=0.05)$, The Null hypothesis is rejected. Hence, The attributes satisfaction with product performance and product return behavior are not independent.

\section{Conclusion and Areas of Future Research}

In conclusion, returns and reverse logistics is a relevant problem in the supply chain. Because returns are an inevitable portion of the customer experience, retailers should exploit them for value such as increased lifetime customer loyalty through positive returns experiences. From the study, it is observed that product brand has no effect on product return behaviour ie., brand may not be the only reason for product returns. Also, product performance and product return behaviour are not independent.. In order to reduce commercial return rates, it is suggested that retailers can resort to a number of strategies such as home delivery, follow up calls, toll-free help lines and information sharing about reasons for returns so as to determining the factors that significantly impact commercial returns and sufficient resources can be 
allocated to reduce return rates. Online sales has become a more important aspect of the retail industry and thus future research should investigate the impact of return policies on ecommerce.

There are several areas where further study could be useful. Firstly, doing an empirical study to more closely examine the different results online returns and in-store results elicit from customers i.e., Pinpointing exactly what types of service and what elements online and in-store returns management should utilize can help to increase customer service metrics and ensure long term customer satisfaction. This will help retailers through increased sales and a higher amount of face time with which they are able to impress their customer and increase customer loyalty over time.

\section{References}

1. J. Andrew Petersen (University of North Carolina at Chapel Hill) and V. Kumar (Georgia State University), Journal of Marketing Research, Apr. 2015, vol. 52, no. 2 : Perceived Risk, Product Returns, and Optimal Resource Allocation: Evidence from a Field Experiment

2. Elzinga, D., S. Mulde.r, and O.J. Vetvik, The consumer decision journey. McKinsey Quarterly, 2009. 3: p. 96-107.

3. Dale S. Rogers, Douglas M. Lambert, Keely L. Croxtonand Sebastián J. GarcíaDastugue(2002) :The Returns Management Process

4. V. Daniel R. Guide Jr, Luc Muyldermans, Luk N. Van Wassenhove(2005): HewlettPackard Company Unlocks the Value Potential from Time-Sensitive Returns Forrester Consulting (2008):Crafting a Returns Policy that Creates a Competitive Advantage Online.

5. Gilvan C. Souza and Future Research (2013): Closed-Loop Supply Chains.

6. A Critical Review Guangzhi Shang (2014):Three Essays on Consumer Product Returns 
7. Joy Deep Srivastavaand Nicholas Lurie(2001):A Consumer Perspective on PriceMatching Refund Policies. Effect on Price Perceptions and Search Behaviour

8. Khan, S.A., Liang, Y. and Shahzad, S. (2015) : An Empirical Study of Perceived Factors Affecting Customer Satisfaction to Re-Purchase Intention in Online Stores in China. Journal of Service Science and Management, 8,291-305. http://dx.doi.org/10.4236/jssm.2015.83032

9. Narayan Janakiramana, Holly A. Syrdalb, Ryan Freling(2015): Note The Effect of Return Policy Leniency on Consumer Purchase and Return Decisions. A Meta-analytic Review

10. Richins, M.L., et al (2008) Consumption Emotions, in Product Experience, Elsevier: San Diego. p. 399-422.

11. Sean O’Neill and Julian Chu: Online Returns Management Strategies

12. Tamira King, Charles Dennis, Len Tiu Wright (2007): Myopia, Customer Returns and the Theory of Planned Behaviour

13. Tamira King, Charles Dennis and Joanne McHendry (2007): The Management of Deshopping and its Effect on Service. A Mass Market Case Study

14. Robert Swinney (2011): Selling to Strategic Consumers When Product Value Is Uncertain.The Value of Matching Supply and Demand

15. ThiloPfrang(2015):Behavioural Appeals to Influence Product Return Behaviour Theoretical Foundations and Experimental Applications

16. Yeon-Koo Che(1996): Consumer Return Policies for Return Good

17. Zhi Pei,AudheshPaswan, Ruiliang Yan(2014): E-tailer's return policy, consumer's perception of return policy fairness and purchase intention 